\title{
Teaching as a Calling and Well-Being of Slovenian and Croatian Teachers
}

\author{
Polona Gradišek \\ University of Ljubljana, Faculty of Education, Ljubljana, Slovenia \\ Sonja Pečjak \\ University of Ljubljana, Faculty of Arts, Ljubljana, Slovenia \\ Majda Rijavec and Lana Jurčec \\ University of Zagreb, Faculty of Education, Zagreb, Croatia
}

\begin{abstract}
In a sample of 347 elementary school subject teachers from Slovenia $(N=176)$ and Croatia $(N$ $=171$ ), the authors investigated teachers' orientations to work (as a job, a career, and a calling) and their well-being with respect to different stages of teachers' professional development. Results have shown the presence of a calling orientation to work and its positive relationship to job satisfaction and life satisfaction. Although significant differences between Slovenian and Croatian teachers were not expected due to shared historical, cultural and political background, some interesting differences were observed. The results of MANOVA showed that teachers differed significantly in their work orientations regarding nationality and the length of their working experience. Results were discussed in the context of stages of professional development and the social status of teachers in both countries.
\end{abstract}

Keywords: calling, job, career, teachers, well-being, Slovenia, Croatia

\section{Introduction}

Teaching is a complex and challenging work that requires the highest standards of professional engagement (Lobene \& Meade, 2013). Teachers are the key agents in today's knowledge society; however, their profession is often regarded as less attractive than many other professions (Čepić \& Kalin, 2017). Teachers must overcome numerous challenges to be able to successfully pursue their careers: low salaries, rare opportunities for in-service education or developing a (vertical) career,

Polona Gradišek, Faculty of Education, University of Ljubljana, Kardeljeva ploščad 16, 1000 Ljubljana, Slovenia. E-mail: polona.gradisek@pef.uni-lj.si 
frequent changes of curricula, increasing pressure from parents, etc. We believe that an important motivating factor that helps teachers face these challenges, is a perception of teaching as a calling. However, as professional and personal lives of teachers are intertwined and affect one another, stages of teachers' professional development must be taken into account when analysing teachers' perceptions of their careers.

\section{Orientations to Work: Job, Career, Calling}

Researchers distinguish three orientations to work: as a job, a career, and a calling (Bellah, Madsen, Sullivan, Swidler, \& Tipton, 2008; Wrzesniewski, 2003; Wrzesniewski, McCauley, Rozin, \& Schwartz, 1997). Majority of studies focused on the calling orientation (e.g., Harzer \& Ruch, 2012; Peterson \& Park, 2006; Peterson, Park, Hall, \& Seligman, 2009) while the other two orientations have been studied less extensively.

Individuals who perceive their work as a job focus primarily on the financial rewards (Bellah et al., 2008; Wrzesniewski, 2003; Wrzesniewski et al., 1997). Their work represents a source of material benefits which enable them to fulfil lower needs, such as safety, physiological and financial needs. These individuals see their work as a necessity and source of financial security, and not as a fulfilment of professional desires and goals. Work is not a central part of their identity.

Career orientation is characterized by a focus on the advancement and achievement of professional goals (Bellah et al., 2008; Wrzesniewski, 2003; Wrzesniewski et al., 1997). Individuals see their current work as a starting point oriented towards desired goals in near future. Their work enables them to satisfy their needs for achievement, status, and power. These individuals invest more in their professional identity than those with a job orientation.

Individuals with a calling orientation focus primarily on the socially useful work (Bellah et al., 2008; Wrzesniewski, 2003; Wrzesniewski et al., 1997). They find their work rewarding and it represents one of the most important domains of their lives. Material benefits are not as crucial as their contribution to society. They invest much in their professional identity.

There has been a growing interest in research of the calling orientation to work. For example, in the period from 2007 to 2012, the number of scientific publications related to calling tripled as compared with publications before 2007 (Duffy \& Dik, 2012; Hall \& Chandler, 2005). In its beginnings, a notion of a calling was related to religion and was described as a divine inspiration to do morally responsible work (Hall \& Chandler, 2005). Later, calling has lost its religious connotation, and researchers have aimed to form a clear definition of the concept (Lobene \& Meade, 2013). Calling stems from individuals' inner motivation, which leads them to seek meaning and purpose of their professional paths. One's calling can be discovered by self-observations and in-depth self-reflection; and its meaning lies in the realization 
of one's life purpose and personal fulfilment (Hall \& Chandler, 2005; Wrzesnievski, 2003; Wrzesnievski et al., 1997).

Researchers agree that the individuals with a sense of a calling feel that their work contributes significantly not only to their personal fulfilment and sense of purpose but to other people and society as well (Bellah et al., 2008; Hall \& Chandler, 2005; Wrzesnievski, 2003; Wrzesnievski et al., 1997). When trying to distinguish the notion of a calling from other similar constructs, such as commitment to work, professional dreams and flow at work, researchers underline some elaborated aspects of a calling. Duffy and Sedlacek (2007) list three essential elements of the notion of a calling: 1) a sense of an innate power that motivates the individual towards the task realization; 2) a search for one's meaning and striving to its achievement; 3) orientation towards the others. Weiss, Skelley, Hall, and Haughey (2003) similarly underline the importance of the awareness of the notion of a calling: individuals should be aware of their calling and that their work serves others. Further on, Novak (1996) stresses some preconditions for perceiving a calling: individuals should be motivated for searching for their calling, as the process of searching demands reflection, thinking, conversations, and perseverance. One's calling should match one's talents and abilities, and it is important that an individual loves his chosen work, so it can energize him and be rewarding.

In the past, researchers mostly focused on the objective measures of success or achievement, however, in today's world of constant changes and pursuing different paths in one's career, the importance of individual, subjective measures of success are highlighted, such as work satisfaction and subjective perception of success. In addition, when talking about the notion of a calling, the subjective, personal experience of an individual is underlined. For individuals who perceive their work as a calling, subjective experience of success is more important in comparison to those individuals who perceive their work as a job or a career (Bellah et al., 2008). Hall and Chandler (2005) state that a sense of a calling can be perceived in any kind of work, however, Lobene and Meade (2013) point out that the question, whether calling can be perceived in any work, remains open.

\section{Teaching as a Calling}

It is not clear how often teachers perceive their work as a calling, as its importance for teachers has often been discussed, but rarely empirically studied (Bullough \& Hall-Kenyon, 2012). However, studies show that it is a rather frequent phenomenon. Researchers have been using different measures of the calling orientation; thus, it is difficult to directly compare their findings. For example, Dinham and Scott (2000) report that $49 \%$ of Australian, $45 \%$ of English, and $46 \%$ of New Zealand teachers agreed with the statement "I have always wanted to become a teacher.", which is obviously related to calling. Teachers in the study of Bullough and Hall-Kenyon (2012) reported high levels of the perception of a calling. It seems 
that certain characteristics of teaching, such as, for example, working with the youth, contribute to work satisfaction of teachers (Richardson \& Watt, 2006), and this could indirectly lead to the perception of a calling.

The perception of teaching as a calling is related to numerous positive outcomes for teachers. Buskist, Benson, and Sikorski (2005) reported that teachers with a sense of a calling feel strong positive emotions towards the subject they are teaching, towards their students and the teaching in general. They see their work as rewarding and fulfilling, and they radiate energy and enthusiasm while teaching. Day, Sammons, Stobart, Kington, and Gu (2007) stress the importance of teachers' perception that they significantly contribute to the lives of their students - these teachers are more effective in the classroom. Day et al. (2007) also point out that good teachers are those who not only master didactics and the content knowledge but are also committed to teaching, to their students, learning, and learning achievements. In the study of Serow (1994), pre-service teachers who agreed with the statement that teaching is a calling in their lives, showed more enthusiasm and commitment to the idea of a teaching career, were more aware of teachers' potential influence on the others, less concerned about sacrifices that teaching might bring, and were more willing to take on additional working tasks in comparison with the ones who did not agree with the statement. Similar findings were reported by Bullough and Hall-Kenyon (2012) - teachers with a sense of a calling were more committed to teaching, identified strongly with their profession and were oriented towards the well-being of their students.

\section{Work Orientations in Relation to Life Satisfaction and Job Satisfaction}

Hall and Chandler (2005) suggested that deep feelings of satisfaction and subjective success can be achieved when one feels a presence of a calling. Some empiric studies examined the relationship between well-being and the calling: adults who perceive their work as a calling show higher levels of satisfaction with life and work (Jurčec \& Rijavec, 2015; Miljković, Jurčec, \& Rijavec, 2016; Wrzesnievski et al., 1997) and are more efficient at work (Serow, 1994). It seems that such individuals devote more time and effort to their work, are more adaptable and ready to change (Hall \& Chandler, 2005), and find more meaning in their work (Miljković et al., 2016). Moreover, research has shown that individuals with the sense of a calling express fewer intentions for early retirement, less absenteeism, their work represents one of key domains in their life and they find it rewarding (Peterson et al., 2009; Wrzesniewski et al., 1997). Lobene and Meade (2013) reported positive relationship between the sense of a calling and work efficiency, affective commitment to organization and work satisfaction, and negative relationship with intentions and desires toward changing jobs. Higher work efficiency is explained by deeper interest and commitment to work of the individuals with the calling orientation.

Job and career orientations to work have not been studied extensively in relation to well-being. There is some evidence, however, that people who perceive their work 
as a job and a career, report lower life satisfaction than those with the calling orientation to work (Wrzesniewski et al., 1997). Peterson et al. (2009) reported negative correlations between job and career orientation in relation to life satisfaction.

\section{Teachers' Professional Development}

There are several models that describe stages of a teacher's career and focus on different aspects of professional lives of teachers. For example, Day et al. (2007) introduced a model of teachers' professional life stages, where they stress the connectedness between teachers' work, life, and effectiveness at work. Beginning teachers $(0-3$ years of service) are committed to work and need support to cope successfully with different challenges they face as novices. In the following years, teachers are shaping their professional identity and are working on their sense of efficacy in the classroom (4 - 7 years of service). Later, changes in the role and identity of teachers take place, bringing more and more tensions ( 8 - 15 years of service). Teachers with around 20 years of service are often more competent, selfconfident, and effective in classrooms in comparison with their younger and older colleagues. The most experienced teachers (more than 24 years of service) find their satisfaction in the increasing knowledge of their students and their positive relationship with students. However, some older teachers experience health problems or feel they are overloaded with work, which can lead to feelings of tiredness and disappointment, and finally towards retirement.

Huberman's (1993) renowned model of teachers' professional life cycle describes two possible paths of a teacher's career: a harmonic path, which results in teacher's satisfaction and sense of a calling; and a problematic path, which leads to teacher's disengagement and dissatisfaction at the point of their retirement. At the beginning of a teaching career, teachers enter the stage of survival and discovery (1 - 3 years of service), followed by stabilization (4 - 6 years of service), experimentation/diversification or reassessment ( $7-18$ years of service), serenity or conservatism (19 - 31 years of service) and (serene or bitter) disengagement (31 - 40 years of service).

For a clearer comparison of teachers' career stages from different perspectives and authors, we used Javrh's (2007) division of teachers' careers, based on Huberman's (1993) model and adapted according to the results of several in-depth interviews with Slovenian teachers: early (up to 10 years of service), middle (10 - 19 years of service) and late/mature stage (divided further into two stages: 20 - 30 years of service and more than 30 years of service). In these interviews, Javrh (2007) assessed general perceptions of teachers about their careers, history of teachers' work experience, future plans, and influence of in-service educational opportunities on the career development. Additionally, qualitative analysis of several teachers' biographies was conducted to enable the comparison of the Swiss Huberman's 
(1993) model and the Slovenian context. The main difference lies in the early end of the Huberman's (1993) first stage (survival and discovery), followed by the early stabilization stage; this resulted in the possibility of merging the first two stages into one, the early stage (up to 10 years of service).

\section{Aim of the Study and Hypotheses}

The aim of the study was to compare work orientations and well-being of Slovenian and Croatian teachers regarding their career stages. As teachers' motivation and effectiveness are changing over the professional life stages (Day et al., 2007) or professional life cycles (Huberman, 1993), we hypothesised that teachers' sense of a calling may also be changing over different stages of professional development.

Slovenia and Croatia share historical experience transitioning from a socialist to a democratic system, with transition process bringing economic hardship and increased stress for people of different professions. Both countries have been facing recession during the last decade, resulting in severe austerity measures in public sector and restriction of career advancement for several years, including during the time when the data was collected for our study. There have been several educational reforms in both countries and rare possibilities for professional development of teachers. Based on shared historical and cultural milieu, as well as similar educational systems that were unified in the past, we do not expect significant differences between Slovenian and Croatian teachers. But we do expect differences among teachers at different stages of professional development in relation to their orientations to work (a job, a career, or a calling).

According to previous research findings (e.g., Bullough \& Hall-Kenyon, 2012; Serow, 1994), we hypothesized that teachers in both sub-samples would perceive their work primarily as a calling (H1). We hypothesized that job and calling orientation would be more characteristic for beginning teachers and teachers at the end of their careers, while career orientation would be more typical for teachers in the middle of their career (e.g., up to 20 years of service), according to Day et al. (2007) and Huberman (1993) professional life stages/life cycles (H2).

Furthermore, we assumed a positive relationship between the sense of a calling and well-being of teachers, measured as job satisfaction and life satisfaction (H3). So far, research has shown positive relationship between calling and job satisfaction (Loebene \& Meade, 2013; Peterson et al., 2009; Wrzesniewski et al., 1997), as well as life satisfaction (Peterson et al., 2009; Wrzesniewski et al., 1997), although Hirschi and Herrmann (2012) did not find a clear relationship between calling and life satisfaction. 


\section{Method}

\section{Participants}

The sample consisted of 347 elementary school subject teachers, 176 from Slovenia (50.7\%) and 171 from Croatia (49.3\%), predominantly female teachers $(87 \%)$, which reflects typical gender structure in teaching profession in both countries. Teachers from rural and urban areas were equally represented $(50 \%$ of teachers from the Slovenian sample were teaching in the capital city with suburbs and $53.8 \%$ of teachers from the Croatian sample; the rest of teachers were teaching in rural areas). In order to provide complete anonymity of the participants, the age of the participants was not collected, and the information about the career stage was collected only in intervals (and not the exact number of years of service). Table 1 shows the distribution of teachers from the sample at different career stages.

Table 1

Distribution of the Research Sample Regarding Career Stages

\begin{tabular}{llccc}
\hline Career stage & & $\begin{array}{c}\text { All } \\
(N=347)\end{array}$ & $\begin{array}{c}\text { Slovenian } \\
\text { sub-sample }\end{array}$ & $\begin{array}{c}\text { Croatian } \\
\text { sub-sample }\end{array}$ \\
\hline Early & $\begin{array}{l}\text { up to 10 years of } \\
\text { service }\end{array}$ & $29.1 \%$ & $29.5 \%$ & $28.7 \%$ \\
\hline Middle & $10-19$ years of service & $27.7 \%$ & $16.7 \%$ & $28.7 \%$ \\
\hline Late/mature I & 20-30 years of service & $23.3 \%$ & $26.7 \%$ & $19.9 \%$ \\
\hline Late/mature II & $\begin{array}{l}\text { more than 30 years of } \\
\text { service }\end{array}$ & $16.4 \%$ & $14.8 \%$ & $18.1 \%$ \\
\hline
\end{tabular}

\section{Instruments}

Three measures were used in the study: A Work-Life Questionnaire, Satisfaction with Life Scale and a measure of work satisfaction.

The Work-Life Questionnaire (WLQ; Wrzesniewski et al., 1997) consists of three short scenarios with descriptions of three persons who perceive their work as a job (person A), a career (person B) and a calling (person C). Participants rated each scenario from 1 (not at all like me) to 4 (very much like me). Sample items from the scenarios are the following (Wrzesniewski et al., 1997, p. 24):

- Job orientation: Person A works primarily to earn enough money to support his life outside of his job. If he was financially secure, he would no longer continue with his current line of work but would rather do something else instead. 
- Career orientation: Person B basically enjoys his work but does not expect to be in his current job five years from now. Instead, he plans to move on to a better, higher-level job. He has several professional goals for his future.

- Calling orientation: Person C's work is one of the most important parts of his life. He is very pleased that he is in this line of work. He tends to take his work home with him and on vacations, too. He is very satisfied with his work and feels good about his work because he loves it, and because he thinks it makes the world a better place.

Satisfaction with Life Scale (SWLS; Diener, Emmons, Larsen, \& Griffin, 1985) measures the cognitive aspect of satisfaction with life. A result on the scale represents one's general estimation of the quality of his life according to personal criteria. The scale consists of 5 items. Slovenian teachers responded on a 7-point Likert scale (1 totally disagree, 7 - totally agree) and Croatian teachers on a 5-point Likert scale (1 - totally disagree, 5 - totally agree). Reliability of the scales was $\alpha=.84$ in Slovenian and $\alpha=.86$ in Croatian sample.

Job satisfaction was measured with the item "I am satisfied with my work", which was assessed on a 7-point Likert scale in Slovenian sample and on a 5-point Likert scale in Croatian sample (1 - totally disagree, 5 or 7 - totally agree).

\section{Procedure}

In both countries, the questionnaires were distributed to teachers in a paperpencil form at the end of a school year (May \& June, 2012) by the researchers themselves. Data was collected for the purposes of two separate studies (one in Slovenia and another in Croatia), however, the sampling procedure and the profile of participant teachers were very similar, which enabled the authors to compare the data. Although convenience sampling was used, the authors intentionally collected a comparable number of teachers from urban and rural areas. Participation in the study was completely anonymous and voluntary.

\section{Results}

\section{Data Analysis}

Data was analysed with the statistical computer program IBM SPSS 22. $T$-test and MANOVAs were used to explore differences in work orientations and wellbeing regarding nationality of teachers (Slovenian, Croatian) and the career stage (early, middle, late/mature I\&II). As well-being was measured using different scales (7-point vs. 5-point scale), standardized $z$-values were computed for job satisfaction and life satisfaction and the value 5 was added to omit the negative values. Analyses 
were computed with new, standardized (positive) values, which enabled a direct comparison between the sub-samples.

\section{Teaching as a Job, a Career, or a Calling}

The first aim of the study was to explore to what extent teachers perceived their work as a job, a career, or a calling. In general, teachers agreed mostly with the description of a calling $(M=3.02, S D=0.76)$, followed by the description of a career $(M=2.17, S D=0.83)$, and the least with the description of a job orientation $(M=$ $1.63, S D=0.74)$. Results confirmed the $\mathrm{H} 1$ hypothesis: calling orientation to work was the most intense one of the three orientations in the sample of teachers.

Table 2

Descriptive Statistics of Work Orientations (Job, Career, Calling)

\begin{tabular}{llllllll}
\hline \multirow{2}{*}{ Work orientations } & Sample & $N$ & $M(S D)$ & $t$ & $d f$ & $p$ & $r$ \\
\hline \multirow{2}{*}{ Job } & Slovenia & 173 & $1.75(0.67)$ & 3.00 & 342 & .03 & .16 \\
& Croatia & 171 & $1.52(0.79)$ & & & & \\
& Total & 344 & $1.63(0.74)$ & & & & \\
\hline \multirow{3}{*}{ Career } & Slovenia & 173 & $2.15(0.84)$ & 0.41 & 342 & .68 & .02 \\
& Croatia & 171 & $2.19(0.83)$ & & & & \\
\hline \multirow{3}{*}{ Calling } & Total & 344 & $2.17(0.83)$ & & & & \\
& Slovenia & 173 & $2.81(0.78)$ & 5.44 & 344 & .00 & .28 \\
& Croatia & 171 & $3.23(0.68)$ & & & & \\
\hline
\end{tabular}

Note. Effect size $r$ was calculated using the formula $r=\sqrt{\frac{t^{2}}{t^{2}+d f}}$.

We found some significant differences between Slovenian and Croatian subsamples: Slovenian teachers perceived teaching as a job to a higher extent than their Croatian colleagues, while Croatian teachers reported more presence of a calling than Slovenian teachers. However, there were almost identical perceptions of a career orientation in both samples.

Contrary to our expectation of similar perception of orientations to work for Slovenian and Croatian teachers, we found some significant differences. In order to further examine these differences, MANOVA was conducted, where we used work orientations (job, career, calling) as dependent variables and nationality and the career stage (e.g., number of years of service) as independent variable.

The multivariate result was significant for nationality (Pillai's Trace $=0.078$, $F(3,322)=9.04, p<.001$, partial eta squared $=.078$ ) and for the career stage (Pillai's Trace $=0.10, F(9,972)=3.83, p<.001$, partial eta squared $=.034)$. The interaction 


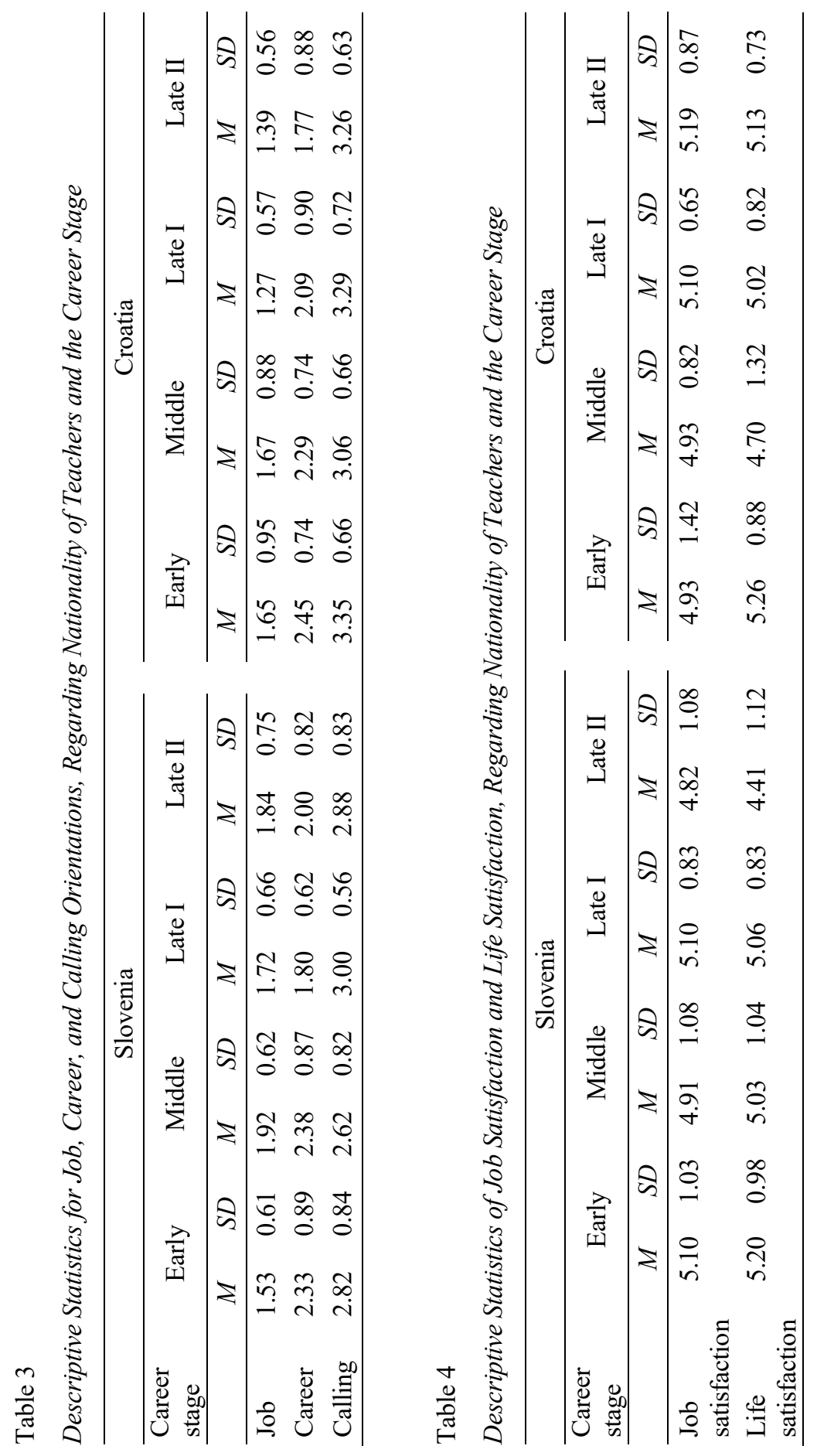


of nationality and the career stage was also significant (Pillai's Trace $=0.057, F(9$, $972)=2.10, p<.027$, partial eta squared $=.017)$, indicating that teachers differ significantly in their work orientations regarding their nationality and the length of their working experience. Post-hoc test showed significant differences for career orientation between teachers at the early and middle career stage and with teachers with both late/mature stages (I and II) ( $p=.001$ for early vs. late stage, $p=.005$ for middle vs. late stage); there were no significant differences for the other two work orientations regarding the years of working experience. Therefore, hypothesis $\mathrm{H} 2$, in which we expected different work orientations regarding teachers' career stages, was rejected: only career orientation differed significantly according to the number of years of service. Interestingly, job and calling orientations showed similar patterns for teachers from both countries, while career orientation showed a different pattern in each country - difference is visible for teachers in the first and second late/mature stages (see Figure 1).

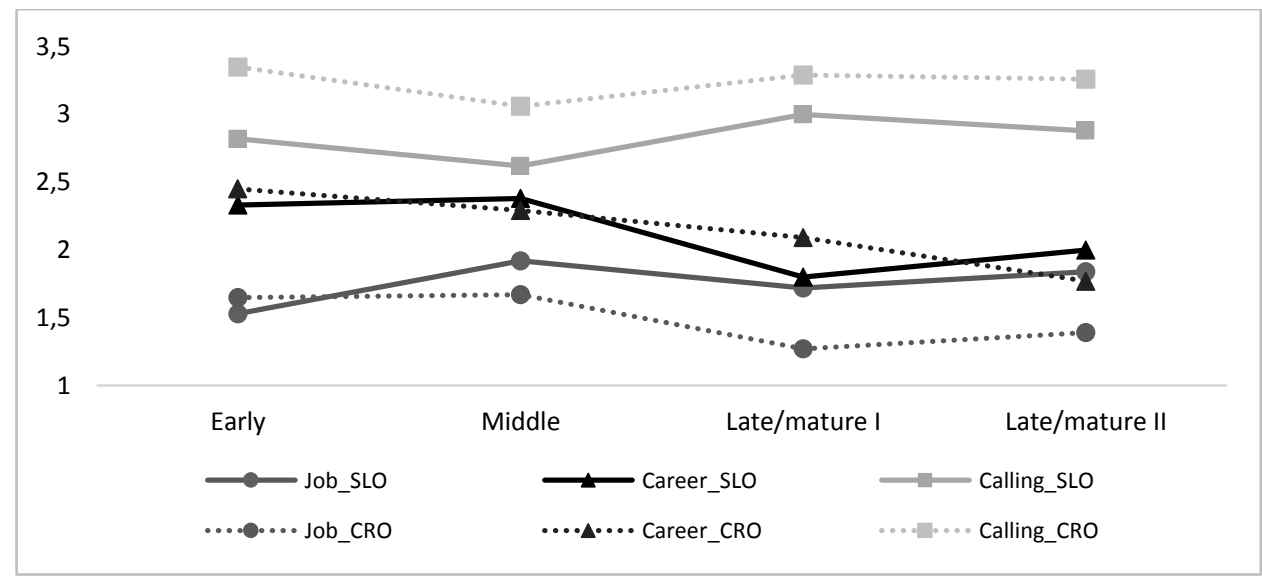

Figure 1. Work orientations of Slovenian and Croatian teachers across career stages.

\section{Well-being of Teachers}

MANOVA was used to explore the association between well-being of teachers (measured as job satisfaction and satisfaction with life) and two independent variables: nationality and a career stage.

The multivariate test was non-significant for nationality (Pillai's Trace $=0.003$, $F(2,326)=0.44, p=.65$, partial eta squared $=.003$ ) and for career stage (Pillai's Trace $=0.037, F(6,654)=2.06, p=.056$, partial eta squared $=.019)$; however, for the career stage, the result was close to significance. Interaction between nationality and career stage was also non-significant. Results indicate that Slovenian and Croatian teachers show similar levels of well-being and that teachers at different career stages do not differ in their well-being. 
However, Figure 2 shows an interesting pattern that can indicate a trend which should be further explored: well-being of teachers from both samples decreases from the early to the middle career stage and increases again in the third career stage. But there is a noticeable difference in the final career stage: both job and life satisfaction in Croatian sub-sample increase, whereas both measures of satisfaction in Slovenian sub-sample decrease. Difference in life satisfaction between Slovenian and Croatian teachers at the late/mature II stage is significant $(t(41.65)=2.80, p=0.01)$.

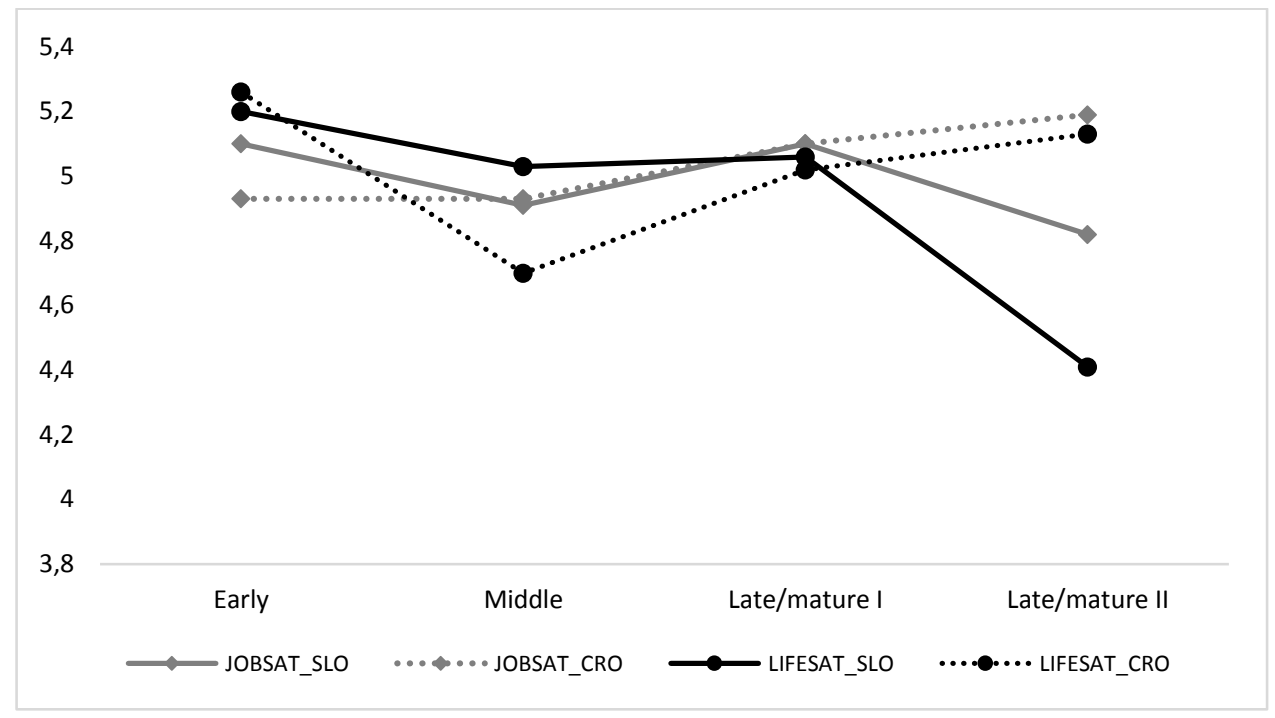

Figure 2. Well-being (job satisfaction and life satisfaction) of Slovenian and Croatian teachers across career stages.

\section{Relationship between Work Orientations and Well-being}

The last aim of the study was to explore the relationship between two aspects of well-being (job satisfaction and life satisfaction) with work orientations, as results from previous studies are not consistent. In our sample of teachers, job satisfaction correlated significantly positively with calling and negatively with job orientation; also, negatively but to a lesser extent, with career. Life satisfaction correlated positively with calling orientation and negatively with job orientation to work (Table 5). Therefore, hypothesis $\mathrm{H} 3$ is confirmed, as both aspects of teachers' well-being are positively related to calling orientation to work. 
Table 5

Pearson's Correlation between Well-Being and Work Orientations

\begin{tabular}{lcccc}
\hline & $\begin{array}{c}\text { Job } \\
\text { satisfaction }\end{array}$ & $\begin{array}{c}\text { Life } \\
\text { satisfaction }\end{array}$ & Job & Career \\
\hline Life satisfaction & $.44^{* *}$ & & & \\
Job & $-.42^{* *}$ & $-.22^{* *}$ & & \\
Career & $-.13^{*}$ & -.05 & .11 & \\
Calling & $.32^{* *}$ & $.23^{* *}$ & $-.43^{* *}$ & -.08 \\
\hline
\end{tabular}

${ }^{*} p<.05 ;{ }^{* *} p<.01$.

\section{Discussion}

The central focus of the study was well-being of teachers and the way they perceived teaching - as a job, a career, or a calling. Two sub-samples of Slovenian and Croatian teachers were compared in the study, where no significant differences were assumed, as both countries share common history and still have comparable school systems. Emphasis was put on exploring differences in well-being and work orientations that may arise from different challenges, characteristic for different career stages of teachers.

\section{Teaching as a Job, a Career, or a Calling?}

Results of the present study are in line with previous research findings, where authors reported common presence of a calling in teachers (e.g., Bullough \& HallKenyon, 2012; Buskist et al., 2005; Dinham \& Scott, 2000; Jurčec \& Rijavec, 2015; Miljković et al., 2016). Teachers from our sample agreed mostly with the description of a calling, and the least with the description of a job orientation, therefore we concluded that calling orientation to work was the most intensive in the sample of teachers. We found some significant differences between Slovenian and Croatian sub-samples: Slovenian teachers perceived teaching as a job to a higher extent than their Croatian colleagues, while Croatian teachers reported more presence of a calling than Slovenian teachers. In a recent study by Šteh, Kalin, and Čepić (2017), Croatian teachers agreed to a very high extent (and higher than their Slovenian colleagues) with the item "Teaching profession is among the most important ones in a society", where we can recognize a presence of a calling orientation to work. As Croatian teachers are less satisfied with the financial aspects of their work and feel less financially independent in comparison with Slovenian teachers (Šteh et al., 2017), their higher calling orientation (and lower job orientation in comparison with Slovenian teachers) can serve as an important buffer against perceived negative aspects of teaching profession and also as an important source of motivation (Hall \& 
Chandler, 2005). However, Slovenian teachers also perceive that social status of teachers has been deteriorating: in both Croatia and Slovenia, teachers were ranked $9^{\text {th }}$ among 10 different professions (from medical doctors, lawyers, to actors and journalists) (Šteh et al., 2017), which is obviously very low and alarming; preschool teachers were ranked $10^{\text {th }}$. Several international studies stress that teachers' roles and demands are increasing, while social status and reputation of teachers is stagnating or even deteriorating in comparison with other professions (e.g., EC, 2012; UNESCO, 1998). According to Šteh et al. (2017), Slovenian and Croatian teachers believe that such negative reputation of the teaching profession negatively affects their job satisfaction. However, low job satisfaction was not recognized in teachers from our sample.

An interesting result was observed for the career orientation to work, where there were differences between teachers at the early and middle career stage with teachers at the late/mature stages I and II, who expressed significantly lower career orientation. It seems that at around 20 years of service career aspirations of teachers decrease, possibly due to the governmental system of career advancement, when teachers reach the highest career point regarding their title and income increase, or due to a decreased need to prove themselves in the eyes of their colleagues and students, with less engagement and reassessment of career goals - as they perceive themselves as competent teachers (Čepić, Kalin, \& Šteh, 2017; Javrh, 2008). In Javrh's (2007) model, teachers at the first late/mature career stage can, on the other hand, feel tired or burned-out, resulting in feelings of helplessness, similar as in Huberman's (1993) model; however, this was not observed in our sample. When analysing career orientation to work, it must be taken into account, that the scenario from the questionnaire might not adequately measure teachers' career orientation, as it was designed for general population samples. Teachers might have not complied to this scenario even if they were predominantly oriented towards career, considering the economic situation and available options of changing the job in Slovenia and Croatia at the time of the data collection, which were both pretty poor.

\section{Well-being of Teachers}

When we measured well-being of teachers, there were no significant differences regarding nationality of teachers and the career stages. However, an interesting pattern was observed (though not statistically significant): well-being of teachers from both sub-samples decreased from the early to the middle career stage and increased again in the third career stage. Teachers at the beginning of their careers (at the early career stage - up to 10 years of service) are usually the youngest teachers, who in comparison with their colleagues in the later professional life phases do not (yet) feel many difficulties with balancing personal and professional life (Day et al., 2007). There was a noticeable difference in the final career stage in our data: both job and life satisfaction in Croatian sub-sample increased, whereas both measures of 
satisfaction in Slovenian sub-sample decreased. Huberman (1993) describes two possible career outcomes in his model of professional life cycles: harmonic and problematic. It seems that Croatian teachers succeeded to a higher extent to evaluate and accept differences between their initial and current levels of enthusiasm, activism and energy, and accepted their real self in their professional roles; Slovenian teachers, on the other hand, might have noticed more intergenerational differences between them and students, become more discontent with communication with students and with administrative work, become more rigid, stubborn and reluctant to innovations, as Huberman (1993) described the final career stage. This aspect should be studied in future studies on larger samples of teachers from both countries, in order to find explanations for these beliefs of teachers. As job and life satisfaction are positively related, they influence one another, meaning that life circumstances of teachers must be taken into account when interpreting job satisfaction, e.g., (un)willingness to retire and teachers' health.

\section{Relationship between Work Orientations and Well-being}

Calling orientation to work was positively related to well-being of teachers, which is consistent with previous research findings (e.g., Lobene \& Meade, 2013; Jurčec \& Rijavec, 2015; Miljković et al., 2016; Peterson et al., 2009; Wrzesniewski et al., 1997). Job orientation was negatively related to well-being, as well as career, but to a lesser extent. This was expected, as job-oriented individuals focus primarily on the financial aspects of their work in order to earn enough for living, and do not focus on the fulfilment of their professional goals and wishes. It must be taken into account that teaching career does not adequately enable teachers to be financially secure, as reported in a study of Šteh et al. (2017), so this could explain the negative correlation between job orientation and well-being. An interesting observation of Wrzesniewski et al. (1997) was that participants with job or calling orientation answered the same items on the questionnaire of these two orientations with opposite values. It may be suggested that these two orientations could represent opposite aspects of the same factor. Negative correlation between career orientation and job satisfaction might reflect teachers' limited possibilities to "make a career" in both countries, that was already mentioned above.

\section{Practical Implications and Directions for Future Studies}

Teacher's perception of teaching as a calling is related to numerous positive outcomes on the side of the teachers themselves and on the side of their students. Thus, it is meaningful to examine factors that contribute to teachers' calling orientation and to develop strategies for developing and stimulating calling orientation in teachers. Two calling-related meta-competencies, self-awareness and adaptability (Hall \& Chandler, 2005), could be useful in this development process. For achieving the sense of a calling it is crucial for individuals to find purpose and 
meaning in their work, to set and successfully achieve their professional goals, to be committed to work and to recognize their own important contribution in the lives of others. It is meaningful to stimulate teachers towards an active professional goal setting and to enable them to interact with other teachers (e.g., in intervision or study groups) to identify their work as meaningful and important. Another important aspect is, however, that having a sense of a calling at work also results from an interaction between individual and social factors. The latter can stimulate or hinder individual's action in the direction of planned or wanted professional career. In case of objective obstacles on a teacher's professional path, a teacher will require some effort to achieve the calling orientation to work. According to Hall and Chandler (2005), successful adaptation and effective navigation through between demanding circumstances are especially important during the times of challenging economic situation.

When taking into account current economic and political situation in the educational field in Slovenia and Croatia, where teaching profession is not adequately financially evaluated and teachers do not receive deserved reputation in a society (Šteh et al., 2017), individual reflection could help teachers keep or find meaning and purpose of their chosen profession. School administration should shape an environment which will enable teachers to pursue their professional goals and be able to actualise their professional autonomy.

\section{Limitations of the Study}

Some limitations of the study have to be acknowledged. The data was collected for the purposes of two different studies - the samples were comparable, and the instruments used were identical, therefore the authors decided to compare the data from the perspective of two different national contexts. Because there were different answering scales in Slovenian and Croatian samples when assessing well-being (7items vs. 5-items respectively), standardization was used, but the answering scale might still have affected the results. Another limitation is a cross-sectional research design and consequently inability to make causal conclusions. Also, should we have had continuous data of teachers' years of service, a more detailed insight into the relationship between professional development and other studied variables would be possible. In addition, relying solely on self-report is a great shortcoming due to a common-method variance effect. There was a possibility of giving socially desirable answers, especially at the assessment of work orientations. Scenarios from the WorkLife Questionnaires should be transformed into items for self-assessment and items for career orientation should be reconsidered for a teaching profession. Qualitative data regarding teachers' perceptions of their profession in a time-specific sociocultural context could help us better understand teachers' motivations for teaching. Finally, repeating the study on a representative sample would provide an insight to what extent political and administrative demands affect teachers' motivations, wellbeing and perception of their work. 


\section{References}

Bellah, R. N., Madsen, R., Sullivan, W. M., Swindler, A., \& Tipton, S. M. (2008). Habits of the heart: Individualism and commitment in American life. Berkeley, CA: University of California Press.

Bullough, R. V., \& Hall-Kenyon, K. M. (2012). On teacher hope, sense of calling, and commitment to teaching. Teacher Education Quarterly, 39(2), 7-27.

Buskist, W., Benson, T., \& Sikorski, J. F. (2005). The call to teach. Journal of Social and Clinical Psychology, 24(1), 111-122.

Čepić, R., \& Kalin, J. (2017). Profesionalni razvoj učitelja: Status, ličnost i transverzalne kompetencije [Teachers' professional development: Status, personality and transversal competencies]. Rijeka: Učiteljski fakultet Sveučilišta u Rijeci.

Čepić, R., Kalin, J., \& Šteh, B. (2017). Profesionalni razvoj učitelja: Kontekst, perspektive i izazovi [Teachers' professional development: Context, perspectives and challenges]. In R. Čepić \& J. Kalin (Eds.), Profesionalni razvoj učitelja: Status, ličnost i transverzalne kompetencije [Teachers' professional development: Status, personality and transversal competencies] (pp. 21-44). Rijeka: Učiteljski fakultet Sveučilišta u Rijeci.

Day, C., Sammons, P., Stobart, G., Kington, A., \& Gu, Q. (2007). Teachers matter: Connecting work, lives and effectiveness. Maidenhead: Open University Press, McGraw-Hill.

Diener, E., Emmons, R. A., Larsen, R. J., \& Griffin, S. (1985). The Satisfaction with Life Scale. Journal of Personality Assessment, 49, 71-75.

Dinham, S., \& Scott, C. V. (2000). Moving into the third, outer domain of teacher satisfaction. Journal of Educational Administration, 38(4), 374-396.

Duffy, R. D., \& Dik, B. J. (2012). Research on work as a calling: Introduction to the special issue. Journal of Career Assessment, 20(3), 239-241.

Duffy, R. D., \& Sedlacek, W. (2007). The presence of and search for a calling: Connections to career development. Journal of Vocational Behavior, 70, 590-601.

EC. (2012). Supporting the teaching profession for better learning outcomes. Strasbourg: European Comission. Retrieved from http://ec.europa.eu/education/news/rethinking/ sw374_en.pdf

Hall, D. T., \& Chandler, D. E. (2005). Psychological success: When the career is a calling. Journal of Organizational Behavior, 26, 155-176.

Harzer, C., \& Ruch, W. (2012). When the job is a calling: The role of applying one's signature strengths at work. Journal of Positive Psychology, 7(5), 362-371.

Hirschi, A., \& Herrmann, A. (2012). Vocational identity achievement as a mediator of presence of calling and life satisfaction. Journal of Career Assessment, 20(3), 309-321.

Huberman, M. (1993). The life of teachers. New York: Teachers college press. 
Javrh, P. (2007). Fazni model razvoja kariere slovenskih učiteljev [Phase-model of the development of Slovenian teachers' career]. Sodobna pedagogika [Journal of Contemporary Educational Studies], 5, 68-86.

Javrh, P. (2008). Spremljanje in načrtovanje razvoja kariere učiteljev po S-modelu [Monitoring and planning of teachers' career development according to S-model]. Ljubljana: Pedagoški inštitut.

Jurčec, L., \& Rijavec, M. (2015). Work orientations and well/ill-being of elementary school teachers. In S. Opić \& M. Matijević (Eds.), Nastava i škola za net generacije: unutarnja reforma nastave u osnovnoj i srednjoj školi [Teaching and the Net Generation School: An Internal Reform of Teaching in Primary and Secondary School] (pp. 100-110). Zagreb: Učiteljski fakultet Sveučilišta u Zagrebu.

Lobene, E. V., \& Meade, A. W. (2013). The effects of career calling and perceived overqualification on work outcomes for primary and secondary school teachers. Journal of Career Development, 40(6), 508-530.

Miljković, D., Jurčec, L., \& Rijavec, M. (2016). The relationship between teachers' work orientations and well-being: Mediating effects of work meaningfulness and occupational identification. In Z. Marković, M. Đurišić Bojanović, \& G. Đigić (Eds.), Individual and environment: International thematic proceedia (pp. 303-312). Niš, Serbia: Faculty of Philosophy.

Novak, M. (1996). Business as a calling: Work and the examined life. New York: The Free Press.

Peterson, C., \& Park, N. (2006). Character strengths in organizations. Journal of Organizational Behavior, 27, 1149-1154.

Peterson, C., Park, N., Hall, N., \& Seligman, M. E. P. (2009). Zest and work. Journal of Organizational Behavior, 30, 161-172.

Richardson, P. W., \& Watt, H. M. G. (2006). Who chooses teaching and why? Profiling characteristics and motivations across three Australian universities. Asia-Pacific Journal of Teacher Education, 34(1), 27-56.

Serow, R. (1994). Called to teach: A study of highly motivated preservice teachers. Journal of Research \& Development in Education, 27, 65-72.

Šteh, B., Kalin, J., \& Čepić, R. (2017). Status učitelja i učiteljske profesije: pogledi iznutra [Status of teachers and teaching profession: insights]. In R. Čepić \& J. Kalin (Eds.), Profesionalni razvoj učitelja: status, ličnost i transverzalne kompetencije [Teachers' professional development: status, personality and transversal competencies] (pp. 4566). Rijeka: Učiteljski fakultet Sveučilišta u Rijeci.

UNESCO. (1998). World education report 1998 - Teachers and teaching in a changing world. Available at: https://unesdoc.unesco.org/ark:/48223/pf0000110875

Weiss, J. W., Skelley, M. F., Haughey, J. C., \& Hall, D. T., (2004). Calling, new careers and spirituality: A reflective perspective for organizational leaders and professionals. In M. L. Pava \& P. Primeaux (Eds.), Spiritual intelligence at work: Meaning, metaphor, and 
morals. Research in Ethical Issues in Organizations, Volume 5 (pp. 175-201). Amsterdam: Elsevier Ltd.

Wrzesniewski, A. (2003). Finding positive meaning in work. In K. S. Cameron, J. E. Dutton, \& R. E. Quinn (Eds.), Positive organizational scholarship: Foundations of a new discipline (pp. 296-308). San Francisco: Berrett-Koehler.

Wrzesniewski, A., McCauley, C. R., Rozin, P., \& Schwartz, B. (1997). Jobs, careers, and callings: People's relations to their work. Journal of Research in Personality, 31, 21-33.

\title{
Podučavanje kao poziv i dobrobit slovenskih i hrvatskih nastavnika
}

\begin{abstract}
Sažetak
Na uzorku od 347 nastavnika predmetne nastave iz Slovenije $(N=176)$ i Hrvatske $(N=171)$ autori su ispitivali odnos orijentacije nastavnika prema radu (kao posao, karijera i poziv) i njihove dobrobiti u različitim fazama profesionalnog razvoja. Prema dobivenim rezultatima izdvaja se orijentacija prema radu kao pozivu, koja je u pozitivnoj vezi s većim zadovoljstvom poslom i zadovoljstvom životom. Iako se, zbog zajedničke povijesne, kulturne i političke pozadine, nisu očekivale značajne razlike između slovenskih i hrvatskih nastavnika, ipak su uočene neke zanimljive razlike. Rezultati MANOVE pokazali su da su se nastavnici značajno razlikovali u svojim orijentacijama prema radu, ovisno o državljanstvu i duljini radnog iskustva. O rezultatima se raspravlja u kontekstu razumijevanja faza profesionalnog razvoja i socijalnog statusa nastavnika u obje zemlje.
\end{abstract}

Ključne riječi: poziv, posao, karijera, nastavnik, dobrobit, Slovenija, Hrvatska

Primljeno: 21.9.2018. 